\title{
Chapter 3 \\ The Biogeography of South African Terrestrial Plant Invasions
}

\author{
David M. Richardson (D), Llewellyn C. Foxcroft (D), Guillaume Latombe (D), \\ David C. Le Maitre $\mathbb{D}$, Mathieu Rouget $\mathbb{D}$, and John R. Wilson
}

\begin{abstract}
Thousands of plant species have been introduced, intentionally and accidentally, to South Africa from many parts of the world. Alien plants are now conspicuous features of many South African landscapes and hundreds of species have naturalised (i.e. reproduce regularly without human intervention), many of which are also invasive (i.e. have spread over long distances). There is no comprehensive inventory of alien, naturalised, and invasive plants for South Africa, but
\end{abstract}

D. M. Richardson $(\bowtie)$

Centre for Invasion Biology, Department of Botany and Zoology, Stellenbosch University, Stellenbosch, South Africa

e-mail: rich@sun.ac.za

L. C. Foxcroft

Centre for Invasion Biology, Department of Botany and Zoology, Stellenbosch University, Stellenbosch, South Africa

Conservation Services, South African National Parks, Skukuza, South Africa

G. Latombe

Centre for Invasion Biology, Department of Botany and Zoology, Stellenbosch University, Stellenbosch, South Africa

Centre for Invasion Biology, Department of Mathematical Sciences, Stellenbosch University, Stellenbosch, South Africa

Division of Conservation Biology, Vegetation, and Landscape Ecology, University of Vienna, Vienna, Austria

D. C. Le Maitre

Centre for Invasion Biology, Natural Resources and the Environment, Council for Scientific and Industrial Research, Stellenbosch, South Africa

M. Rouget

UMR PVBMT, CIRAD, La Réunion, France

J. R. Wilson

Centre for Invasion Biology, Department of Botany and Zoology, Stellenbosch University, Stellenbosch, South Africa

South African National Biodiversity Institute, Kirstenbosch Research Centre, Cape Town, South Africa

B. W. van Wilgen et al. (eds.), Biological Invasions in South Africa, Invading

Nature - Springer Series in Invasion Ecology 14,

https://doi.org/10.1007/978-3-030-32394-3_3 
327 plant taxa, most of which are invasive, are listed in national legislation. We collated records of 759 plant taxa in 126 families and 418 genera that have naturalised in natural and semi-natural ecosystems. Over half of these naturalised taxa are trees or shrubs, just under a tenth are in the families Fabaceae (73 taxa) and Asteraceae (64); genera with the most species are Eucalyptus, Acacia, and Opuntia. The southern African Plant Invaders Atlas (SAPIA) provides the best data for assessing the extent of invasions at the national scale. SAPIA data show that naturalised plants occur in $83 \%$ of quarter-degree grid cells in the country. While SAPIA data highlight general distribution patterns (high alien plant species richness in areas with high native plant species richness and around the main human settlements), an accurate, repeatable method for estimating the area invaded by plants is lacking. Introductions and dissemination of alien plants over more than three centuries, and invasions over at least 120 years (and especially in the last 50 years) have shaped the distribution of alien plants in South Africa. Distribution patterns of naturalised and invasive plants define four ecologically-meaningful clusters or "alien plant species assemblage zones", each with signature alien plant taxa for which trait-environment interactions can be postulated as strong determinants of success. Some widespread invasive taxa occur in high frequencies across multiple zones; these taxa occur mainly in riparian zones and other azonal habitats, or depend on human-mediated disturbance, which weakens or overcomes the factors that determine specificity to any biogeographical region.

\subsection{Introduction}

South Africa has a rich diversity of environmental conditions, biota, and a unique socio-political situation. This makes it a fascinating place to explore the many interacting factors that have mediated the introduction and dissemination of particular plant species, and their interactions with resident biota and prevailing environmental conditions that determine their performance as alien species (Richardson et al. 1997, 2011a; Le Roux et al. 2020, Chap. 14; van Wilgen et al. 2020a, Chap. 1; Wilson et al. 2020, Chap. 13). Terrestrial ecosystems in South Africa have been invaded by hundreds of alien plant species. Some of these have very large adventive ranges, and some of these have transformed invaded ecosystems. These invasions pose a major threat to the country's biodiversity, impact negatively on the capacity of ecosystems to deliver goods and services, and in some cases severely threaten human livelihoods (Richardson and van Wilgen 2004; Le Maitre et al. 2020, Chap. 15; O'Connor and van Wilgen 2020, Chap. 16; Potgieter et al. 2020, Chap. 11; Zengeya et al. 2020, Chap. 17).

This chapter focusses on the biogeography of terrestrial plant invasions in the country. It: (1) presents a brief history of alien plant invasions; (2) summarises information on which alien plants are naturalised and invasive; (3) reviews the extent 
of these invasions; (4) examines the broad-scale distribution patterns of naturalised and invasive plants with reference to "alien plant species assemblage zones" defined on the basis of the turnover of alien species; and (5) provides recommendations to improve our understanding of the composition, distribution, and dynamics of the South African naturalised flora.

Other chapters in this book provide complementary details related to the invasion process of plants, including introduction pathways (Faulkner et al. 2020, Chap. 12), environmental (Wilson et al. 2020, Chap. 13) and biotic (Le Roux et al. 2020, Chap. 14) drivers of invasions, impacts of invaders on water resources (Le Maitre et al. 2020, Chap. 15), rangelands (O'Connor and van Wilgen 2020, Chap. 17) and biodiversity (Zengeya et al. 2020, Chap. 18). Issues pertaining to human dimensions (Shackleton et al. 2020, Chap. 24) and management of plant invasions (Foxcroft et al. 2020, Chap. 28; Hill et al. 2020b, Chap. 19; Holmes et al. 2020, Chap. 23; van Wilgen et al. 2020b, Chap. 21) are also covered elsewhere in the book, as is the status of alien plants in other specific ecosystems: freshwater (Hill et al. 2020a, Chap. 4), urban ecosystems (Potgieter et al. 2020, Chap. 11), and off-shore islands (Greve et al. 2020, Chap. 8). The focus of this chapter is on the history and current state of plant invasions in natural and semi-natural ecosystems. Terminology pertaining to alien, naturalised, and invasive plant taxa follows the definitions proposed by Richardson et al. (2000, 2011a): alien taxa are those that do not occur naturally in South Africa and owe their presence here to human actions; naturalised taxa are alien taxa that reproduce regularly, and invasive taxa are naturalised taxa that have spread over considerable distances from sites of introduction.

\subsection{A Brief History of Plant Invasions in South Africa}

Of the alien plant taxa that are currently widespread in South Africa's terrestrial ecosystems few (if any) were present in the region before European colonisation began in the seventeenth century (Deacon 1986; Richardson et al. 1997; see Faulkner et al. 2020, Chap. 12 for an evaluation of evidence for post-1652 plant introductions). There is no evidence that any introduced species became invasive before European colonisation, and no species introduced prior to 1652 is currently a major invader of natural and semi-natural ecosystems. South Africa's large flora of naturalised and invasive alien plants thus comprises almost exclusively taxa that have arrived and been disseminated in the last three and a half centuries.

Plant taxa from many parts of the world have been introduced to South Africa for many purposes (Faulkner et al. 2020, Chap. 12). Some were accidental introductions, but thousands of taxa were intentionally introduced - as agricultural crops, for timber and firewood, as garden ornamentals, to stabilise sand dunes, as barrier and hedge plants, as animal fodder and for other purposes. Wells et al. (1986) reviewed plant introductions associated with several broad phases, from the initial period of European settlement through to "the modern phase" (up to 1985). Two key phases 
were the rise in introductions for forestry in the nineteenth century that declined towards the end of the twentieth century; and introductions of ornamental plants that started in the mid-twentieth century and continue today.

Because of the paucity of trees suitable for forestry in South Africa's flora, and the small area of native forest, hundreds of tree species have been introduced to the country (see Richardson et al. 2003 for a detailed review, and Box 3.1). Experimental introductions of trees began during the Dutch and British colonial periods with the aim of providing timber for construction, shipbuilding, and for amenity plantings, shelter, windbreaks, and fuelwood. Organised government involvement in forestry began in 1872 with the establishment of a forestry department at the Cape. This led to the establishment of plantations of many alien trees, especially species in the genera Acacia, Eucalyptus and Pinus. Wood shortages during World War I stimulated major afforestation efforts. Poynton (1984) lists more than 400 tree species that were successfully cultivated in South Africa, including more than 100 Eucalyptus species, 80 Pinus species and 70 Australian Acacia species (see also Poynton 1979a, b; Poynton 2009). Besides species that were intended for commercial forestry and woodlots, many other trees that were not grown in plantations were introduced, propagated, and promoted by government forestry organisations; these included Acacia cyclops (Rooikrans) and A. saligna (Port Jackson Willow), Jacaranda mimosifolia (Jacaranda), Melia azedarach (Syringa), and Prosopis (Mesquite) species (Poynton 1990, 2009). Widespread planting of many alien tree species for dune stabilisation started in 1830; this created another major pathway for the dissemination of woody alien plants in South Africa. Australian Acacia species (wattles), Casuarina cunninghamiana (Beefwood), Hakea drupacea (Sweet Hakea), Leptospermum laevigatum (Australian Myrtle) and Pinus pinaster (Cluster Pine) were the most extensively planted species for this purpose (Avis 1989). Many alien species were introduced as barrier plants to support agricultural production. Prominent examples of species that were widely planted as hedges or windbreaks in agricultural and rural landscapes and that are now invasive are Eucalyptus camaldulensis (River Red Gum), Biancaea decapetala (syn. Caesalpinia decapetala; Mauritius Thorn), Leptospermum laevigatum, Ligustrum lucidum (Chinese Wax-leaved Privet), Pyracantha angustifolia (Yellow Firethorn), and many species of Cactaceae (Cacti) (Henderson 1983).

The introduction of alien plant species for ornamentation dates back to the establishment of the Cape Colony in 1652 and the Company Gardens in Cape Town, but most initial introductions (as discussed above) were strictly or mainly for utilitarian purposes. The horticultural industry has grown over time and, although South Africa has a rich native flora, the demand for new alien plant species has not abated. Many of South Africa's most widespread invasive plants, especially in areas around human settlements, were introduced and disseminated for their ornamental value (Alston and Richardson 2006; Foxcroft et al. 2008; Donaldson et al. 2014; Jacobs et al. 2014; Cronin et al. 2017; Kaplan et al. 2017; McLean et al. 2017; Canavan et al. 2019). 
While it is possible to provide such broad generalisations, the phases of introduction are taxon-specific. Visser et al. (2017) assessed the pathways of introduction of 256 alien grass species to South Africa. They found that introduction to supplement forage for livestock was by far the dominant pathway, accounting for $62 \%$ of species introductions. Horticulture and soil and stabilisation were the next most common reasons for introductions, followed by the categories "food and beverage" and "raw materials". The cumulative number of alien grass species in South Africa has increased steadily since the early 1800 s and shows no signs of slowing (Visser et al. 2017). As in other parts of the world, new pasture taxa (including species, subspecies, varieties, cultivars, and new plant-endophyte combinations) are increasingly being introduced to South Africa (Driscoll et al. 2014). Although many of the grass species involved are already in the country, the novel genetic material and endophyte variations are changing the risk of such introductions producing invasions with major impacts.

A detailed assessment of the history of introduction of bamboo species (Poaceae subfamily Bambusoideae) to South Africa revealed five main phases of introduction and dissemination. These were associated with (1) intra-African migration of people; (2) the arrival of Europeans; (3) growth of the agricultural and forestry sectors; (4) small-scale domestic use by landowners; and (5) the rise of the "green economy" (Canavan et al. 2019). Each phase created new opportunities for particular uses of bamboo species.

By contrast, there have been only two main phases of Cactaceae introductions. Initial introductions of a few species for agriculture in the nineteenth century (for food, cochineal, and as barrier plants); and in the last few decades the introduction of many species for ornamental horticulture (Kaplan et al. 2017; Novoa et al. 2017). Interestingly, due to correlations between growth forms, life-history traits and usages, most cactus species suitable for agriculture are invasive whereas many of the taxa widely used in horticulture pose minimal risk (Novoa et al. 2015).

This link between reasons for introduction and invasiveness is particularly interesting. The role of forestry in launching and sustaining invasions is well-established (Richardson 1998; Rouget et al. 2002; van Wilgen and Richardson 2012; Donaldson et al. 2014; McConnachie et al. 2015). Many non-woody invasive plants were also introduced, mainly for ornamental horticulture, and the configuration and persistence of plantings has left a strong imprint on invasion patterns (e.g. Foxcroft et al. 2008). Wilson et al. (2007) assessed the spread rates of 62 alien plant species in South Africa, and found that species planted as ornamentals had spread faster than those used for other purposes. In a related analysis, Thuiller et al. (2006) found that the spatial pattern of invasive plants in South Africa was driven by, among other factors, human uses. Many widespread invaders were accidentally introduced and disseminated; important examples are Chromolaena odorata (Triffid Weed), Datura innoxia (Downy Thorn Apple), Tagetes minuta (Khaki Bush) and Xanthium spinosum (Spiny Cocklebur). The current extent and patterns of alien plant invasions are due to interactions between species traits, environmental features, residence time, and the ways in which reasons for introduction have facilitated spread within the 
country (Thuiller et al. 2006; Donaldson et al. 2014). It is not surprising, therefore, that the earliest records of invasion are from species that were introduced for utilitarian purposes, and that most of the new records of invasive plants have been taxa used in horticulture that were intentionally introduced and widely planted.

The most widespread alien plant species in South Africa today, Opuntia ficusindica (Mission Prickly Pear; found in 35\% of all quarter-degree grid cells in South Africa), started expanding its range around planting sites in the 1770s and "had become a serious and troublesome weed" by about 1890 (Annecke and Moran 1978). There are no records of major incursions of other alien plant species into natural vegetation in the 18 th or early 19 th centuries. Widespread invasions of alien plant species in natural ecosystems in South Africa were reported in the mid-1800s when invasive pines introduced for forestry [Pinus pinaster and possibly $P$. halepensis (Aleppo Pine)] began spreading into fynbos in the Western Cape (Richardson et al. 1994; Richardson and Higgins 1998). Other species that were already clearly invasive in the second half of the nineteenth century were $O$. aurantiaca (Jointed Cactus) and X. spinosum. In some cases, the enactment of policies and legislation provides clues on the emergence of major invasions. For example, although early distribution records for $X$. spinosum are scarce, the promulgation in 1861 of the Xanthium spinosum Act points to a major increase in the abundance, distribution and nuisance value of this species in preceding decades (see Lukey and Hall 2020, Chap. 18). Several reports of widespread invasions of Acacia, Hakea and Pinus species appeared in the 1920s and 1930s; by the 1940s large-scale invasions of these taxa occurred in many parts of the Fynbos Biome (reviewed in van Wilgen et al. 2016).

Widespread invasions began later in other parts of South Africa, but there are few detailed reports of the first invasions in the eastern and northern parts of the country. Among species that are currently widespread invaders in the northeastern parts of the country, Lantana camara (Lantana) and Solanum mauritianum (Bugweed), both of which were planted as ornamentals, were widespread in the 1930s and both were listed on the National Weeds Act of 1937. Henderson and Wells (1986) provide the earliest records of naturalisation for a range of species that are now widespread invaders in the Grassland and Savanna Biomes; dates range from the 1770s for O. ficus-indica, the 1870s for Acacia dealbata (Silver Wattle) and A. mearnsii (Black Wattle), to 1907 for Lantana camara and the 1940s for Chromolaena odorata.

Several examples illustrate the very rapid and recent emergence of invasions over large parts of the eastern, northern and interior parts of South Africa by species that are now among the country's most widespread and damaging invasive species. Chromolaena odorata was first recorded in Durban in 1945 and was present in Hluhluwe-iMfolozi game reserve by 1961 (Macdonald and Frame 1988). Goodall and Erasmus (1996) document the spread of this species over large parts of eastern South Africa within 50 years of its arrival in the country. The first records of Lantana camara were from Durban and Cape Town, management efforts were reported as 
early as the 1950s, and there were widespread invasions by the 1960s (Bhagat et al. 2012). The spread of Campuloclinium macrocephalum (Pompom Weed) was first noted in the 1960s around Pretoria, whereafter it spread to other parts of the country (Goodall et al. 2011). Prosopis species (mesquite) began spreading in the arid interior of South Africa in the 1970s and 1980s some 60 years after major plantings (Harding and Bate 1991). Rapid mesquite expansion followed several years of above-average rainfall in the Karoo that created conditions suitable for seed dispersal and seedling establishment. Another, similarly rapid, expansion of mesquite occurred in the 2000s (van den Berg et al. 2013). The 1980s also saw the rapid invasion of Opuntia stricta (Australian Pest Pear) in the Kruger National Park where major invasions grew from scattered foci around Skukuza, where the species was grown as an ornamental plant in tourist villages in the 1950s (Foxcroft et al. 2004). Although first reported in South Africa in 1880, at Inanda in KwaZulu-Natal, Parthenium hysterophorus (Parthenium Weed) remained uncommon until the 1980s when its populations expanded rapidly after Cyclone Demoina caused extensive flooding along the east coast of southern Africa in 1984 (McConnachie et al. 2011). Since then its range has increased rapidly and it is now a major invader over large parts of mesic savannas in eastern South Africa (Terblanche et al. 2016). Similarly, Pyracantha angustifolia only began invading the Grassland Biome in the early 1980s (the first herbarium record for the species is dated 1970 from the Ficksburg district of the Free State); it then spread very rapidly and dense stands of this shrub now occur in many high-altitude grasslands.

\subsection{How Many Taxa? South Africa's Alien, Naturalised and Invasive Flora}

\subsubsection{A National List of the Alien Flora?}

No comprehensive list of the alien flora of South Africa exists, but several publications have made estimations of between 8750 and 9000 alien plant taxa (Le Maitre et al. 2011; Richardson et al. 2011b; Irlich et al. 2014; van Wilgen and Wilson 2018). These estimations seem to be based largely on insights from Glen's (2002) book on the "Cultivated plants of southern Africa". Glen's list was based on herbarium specimens, nursery catalogues and records from plant breeders' rights. It does not include naturalised species that have not been cultivated, such as those introduced as seed contaminants. Discussions with many botanists suggest that the estimate of 8750-9000 alien taxa is conservative. Glen and van Wyk (2016) estimated that there were around 2000 alien tree species in South Africa.

The challenges associated with compiling a definitive alien flora for South Africa, and deciding which taxa reside in different "introduction status" categories (based on their position along the introduction-naturalisation-invasion continuum; Blackburn 
et al. 2011), have been highlighted in several recent studies. For example, Pyšek et al. (2013) noted that $20 \%$ of alien plant species listed in South Africa's Conservation of Agricultural Resources Act had no herbarium records in the country's National Herbarium. There have been efforts to improve the accuracy of inventories of alien plant taxa, and several detailed studies have been undertaken recently to confirm the identity of taxa in groups with poorly resolved taxonomic status and for other important plant groups.

Magona et al. (2018) conducted a comprehensive assessment of the presence of Australian Acacia species (wattles) in South Africa. Using herbarium records, visits to known planting sites, field surveys, and molecular methods, they concluded that although records exists for introductions of 141 species to South Africa, only 33 species are definitely still present, 13 of which are invasive. Importantly, several of the invasive species are not on Glen's list, and many species on Glen's list could not be found at known planting sites. Walters et al. (2011) estimated that around 400 alien species of Cactaceae are present in South Africa, and Novoa et al. (2017) presented evidence that about 300 species of cacti are imported to South Africa annually (though the vast majority of these are not new to South Africa). Currently, 35 species of Cactaceae are invasive (Kaplan et al. 2017). Milton (2004) produced a preliminary list of 113 alien grass species present in South Africa. Visser et al. (2017) updated this inventory, using recorded occurrences from many literature and database sources. They concluded that at least 256 alien grass species are present, 37 of which are invasive. One clade of grasses (subfamily Bambusoideae; 'bamboos') was examined in more detail by Canavan et al. (2019), who found evidence for the presence of 34 currently recognised alien bamboo taxa in South Africa. Jacobs et al. (2017) reviewed evidence for the presence of Melaleuca species (Paperbark Trees; including taxa formerly included in the genus Callistemon) in South Africa. They concluded that at least 36 species are currently present in the country. Le Roux et al. (2010) used molecular methods to confirm the presence of Anigozanthos flavidus (Evergreen Kangaroo Paw), which had been tentatively identified based on morphological features; they also identified a second naturalised species, A. rufus (Red Kangaroo Paw), not previously recorded from South Africa. Taxa within several alien plant genera (e.g. Eucalyptus, Oenothera, Opuntia, Pinus, Prosopis, Rubus, Salix and Senna) are only identified to the genus level in some lists and mapping exercises, and in some cases questionable species identifications are made.

These examples show that, even for very conspicuous and well-studied plant species from taxonomically well-resolved groups (e.g. wattles), further work is needed to confirm the identity and introduction status of alien taxa. The situation is worse for taxa that are less well studied, less conspicuous, or difficult to identify. This has important implications for understanding aspects of the invasion ecology of species (e.g. matching plant species to host-specific bacterial and mycorrhizal symbionts to evaluate the role of mutualisms) and for management (e.g. when considering biological control). 
Hybridisation also complicates the compilation of an alien flora for South Africa. A notable example is the genus Prosopis. Published records detail the introduction of at least seven Prosopis species (P. cineraria, P. glandulosa, P. juliflora, P. laevigata, P. pubescens, P. tamarugo and P. velutina) (Poynton 1990). However, preliminary molecular studies, together with variation in seed morphology, suggest that most populations in South Africa are hybrids, and that at least one previously unrecorded species, P. hassleri, is present (Mazibuko 2012). The presence of $P$. chilensis, $P$. glandulosa, and $P$. laevigata was confirmed, but neither $P$. juliflora nor $P$. velutina, were identified using the selected molecular markers. While the taxonomy of the genus remains problematic, there is no doubt that multiple species were introduced into South Africa (Poynton 1990). Moreover, Mazibuko's (2012) results, suggest that most Prosopis taxa hybridise freely in South Africa and that invasive populations represent a hybrid swarm.

The challenges associated with producing an accurate and definitive alien flora reviewed above point to two main conclusions: (1) lists of alien species for South Africa (like elsewhere) have substantial errors, although the actual error rates are unknown. While some listed species are likely not present, lists generally substantially underestimate the number of alien species that have been introduced; and (2) lists need to be regularly updated based on agreed definitions, current nomenclature, and evidence that species are still present. The production of a register of alien species is a requirement of the national regulations, and the goal is for this to form part of the triennial reports on the status of biological invasions led by the South African National Biodiversity Institute (Wilson et al. 2017a; van Wilgen and Wilson 2018; Wilson et al. 2018).

\subsubsection{A Preliminary Enumeration of South Africa's Naturalised Flora}

We used the list of naturalised plant taxa for South Africa produced for the first national status report on biological invasions for the purposes of this chapter (Appendix 3 in van Wilgen and Wilson 2018). We made a few minor modifications based on our knowledge of the introduction status of many taxa (i.e. their position on the introduction-naturalisation-invasion continuum; Richardson and Pyšek 2012), using published and unpublished information, and correspondence with colleagues. We also made some changes to accommodate recent taxonomic treatments. The list in Supplementary Appendix 3.1 includes 759 taxa, including all 327 plant taxa listed in the national legislation. Even though many taxa have only naturalised in the last few decades, the number of taxa listed here is well below the "at least 1000 candidate species" considered by Wells et al. (1986). This is due to our strict requirement for inclusion as naturalised, namely that there had to be evidence for populations that were self-sustaining for at least 10 years (Pyšek et al. 2004). 

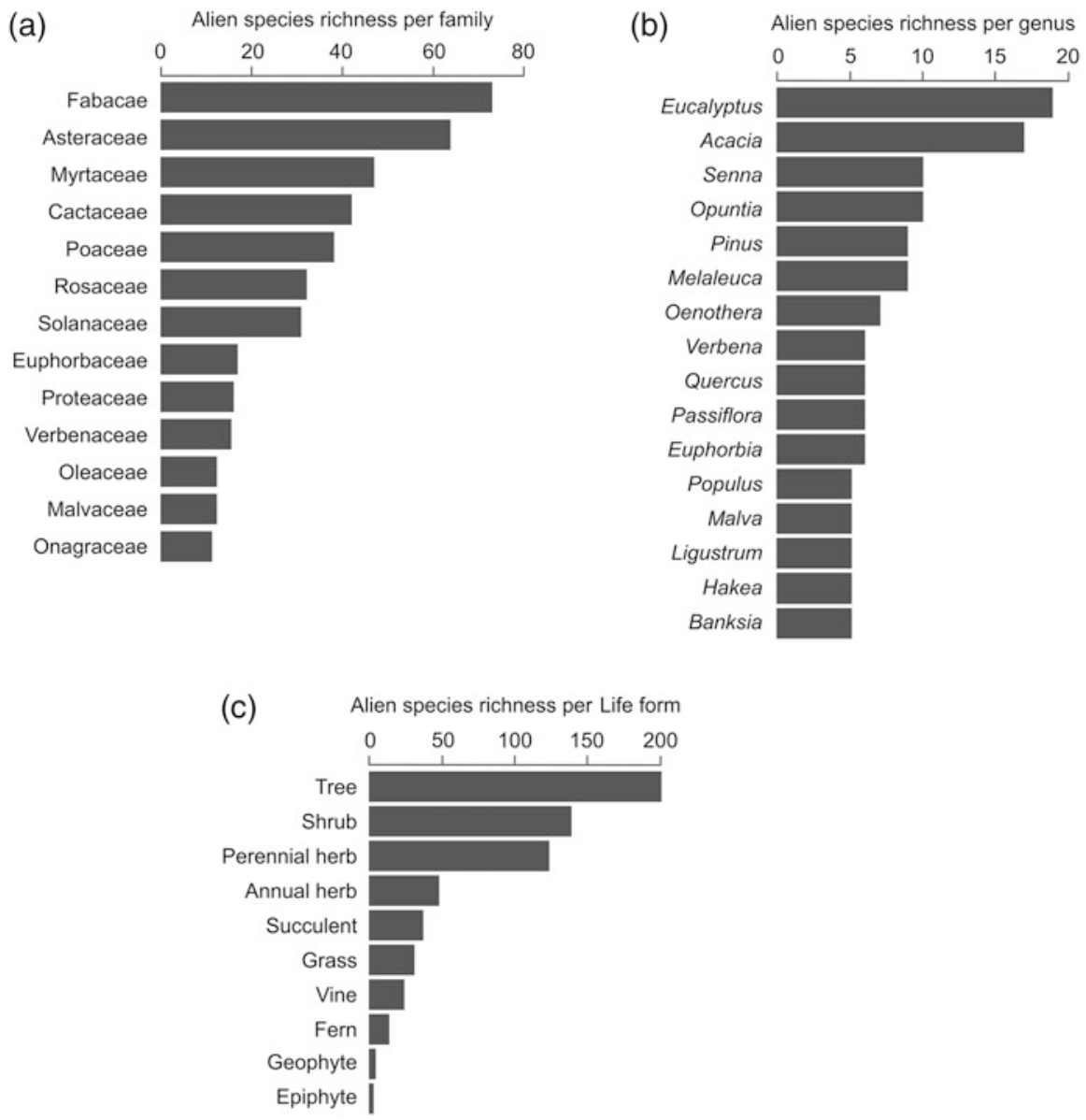

Fig. 3.1 Features of South Africa's naturalised alien flora, showing the dominant (a) families, (b) genera, and (c) plant life forms.

The families with the richest naturalised flora in South Africa are Fabaceae (73 taxa), Asteraceae (64), Myrtaceae (47), Cactaceae (42), and Poaceae (38). These top five families contain $35 \%$ of the alien flora (Fig. 3.1a). Genera with 10 species or more are Eucalyptus (22), Acacia (17), Opuntia (16), Solanum (14), Oenothera (10) and Senna (10) (Fig. 3.1b). An extraordinary feature of the naturalised flora is the dominance of woody plants- $56 \%$ are trees and shrubs (see Box 3.1 and Fig. 3.1c). 


\section{Box 3.1 South Africa: World Capital of Tree Invasions}

The dominance of trees among invaders of natural and semi-natural vegetation is a striking feature of South Africa's naturalised flora. Of South Africa's 759 naturalised plant taxa (Supplementary Appendix 3.1), roughly a third are trees $(240 ; 32 \%)$, following the criteria for separating trees from shrubs proposed by Richardson and Rejmánek (2011) ("perennial woody plants with many secondary branches supported clear of the ground on a single main stem or trunk with clear apical dominance"). Another 36 taxa are generally classified as shrubs, but some may assume tree-like stature. Together, these 276 woody plant taxa make up $36 \%$ of South Africa's naturalised flora. Taxa classified primarily as trees belong to 56 families and 120 genera. Myrtaceae (45 species from 11 genera) and Fabaceae (38 species from 11 genera) are the dominant families.

Genera of alien trees for which invasions have been well studied in South Africa are Acacia, Casuarina, Eucalyptus, Pinus, Prosopis, and Schinus. Insights on invasions of these taxa have contributed substantially to the understanding of tree invasions globally (Richardson et al. 2014; Rundel et al. 2014).

The phenomenal success of trees as invaders in South Africa is probably at least partly due to the massive propagule pressure and long residence time because of repeated introductions and widespread plantings over more than a century. However, several ecosystem types in South Africa appear to be extraordinarily susceptible to invasion and transformation by alien trees.

Species-rich fynbos shrublands are highly vulnerable to invasion by trees from other fire-prone regions of the world. Serotinous Pinus species from Europe and Central and North America, and Australian Acacia species with soil-stored seeds that are stimulated to germinate by fire have invaded vast areas of fynbos, transforming shrubland vegetation into woodlands or forests over several decades (Richardson and Brown 1986; Richardson and Kluge 2008; Richardson and Cowling 1992).

Riparian habitats throughout South Africa have been severely invaded by alien trees, especially species in the genera Acacia, Eucalyptus, Populus, and Salix. These invasions are driven primarily by dispersal of propagules along rivers and through disturbance caused by flood events. These invasions are self-reinforcing in that stands of naturalised plants trap sediments, thereby creating abundant habitat for further establishment of seedlings and detached plant parts (Galatowitsch and Richardson 2005; Holmes et al. 2005). Invasions by these species are widespread in the wetter parts of the country, and also extend along perennial rivers throughout the arid Karoo, and in the Grassland and Savanna Biomes.

Inundation of floodplains during periods of above-average rainfall has triggered invasions of several species in South Africa, notably of Prosopis spp. in the arid interior of the county (Harding and Bate 1991). Groundwater availability appears to limit the extent of these invasions; water in floodplain aquifers is easily 
Box 3.1 (continued)

accessed by the deep roots of Prosopis which sustains high-density invasions. There are also extensive Prosopis invasions along the lower Orange River.

Besides the suite of very widespread and highly damaging invasive trees that are currently the focus of invasive plant management in the country (Marais et al. 2004), a large number of other tree taxa are naturalised but have yet to invade large areas. Many of these are known to be highly invasive in other parts of the world, including Grevillea banksii (Red Silky Oak); Melaleuca quinquenervia (Broad-leaved Paperbark), Mimosa pigra (Giant Sensitive Tree) and Prunus serotina (Black Cherry). Many of the taxa that already occupy large ranges in the country also have the potential to invade much larger areas (Rouget et al. 2004). There is thus a large invasion debt for alien trees in South Africa and more research is needed to improve our understanding of their invasion ecology to guide management.

\subsection{Extent of Invasions}

Two major assessments have been made of the spatial extent of alien plant invasions over large parts of South Africa. Unfortunately, the two assessments used very different methods and focused on particular taxa, types of plants, or areas. This means that they cannot be easily compared to show changes over time (see Supplementary Appendix 3.2). Despite such challenges, the two assessments have shed light on key aspects of plant invasions in South Africa.

Versfeld et al. (1998) reported on a rapid reconnaissance of the extent of alien plant invasions (mainly woody plant taxa) in South Africa, undertaken mostly during 1996 and 1997 to provide information needed to support the prioritisation of control programmes for the newly established Working for Water programme (see van Wilgen et al. 2020b, Chap. 21). This assessment involved a combination of field mapping (some based on historical information), desktop and workshop mapping, and expert consultations. All the taxa known to occur in a mapping unit were listed, most at a species level, though some at a genus level (e.g. Acacia and Eucalyptus were recorded as wattles and eucalypts). It concluded that about 10 million ha of South Africa (about $8 \%$ of the country) had been invaded to some degree by the 180 species that were mapped. The Western Cape had the most extensive invasions, followed by Limpopo and Mpumalanga. KwaZulu-Natal and the Eastern Cape were not assessed at the same level of detail as the other provinces; invasions in these regions were considered to be close to the percentage for Mpumalanga. The assessment showed that invasions are concentrated in the wetter regions of the country, and that the greatest number of invasive species occured in the Western Cape and along the eastern escarpment from KwaZulu-Natal to Limpopo.

A second national-scale assessment of the extent of alien plant invasions was the National Invasive Alien Plant Survey. This assessment, again in support of the Working for Water Programme, was undertaken by the Agricultural Research 
Council mainly during 2007 (Kotzé et al., 2010). This assessment focussed on 28 invasive taxa (mainly trees and shrubs) that are the main targets of the Working for Water programme. The sampling method involved defining homogeneous mapping units, allocating point samples, conducting aerial surveys of those points, and then extrapolating the point data to the mapping unit. (Kotzé et al. 2019). The assessment focused on the mesic parts of the country, and excluded a very large proportion of arid South Africa.

Versfeld et al. (1998) found that invasions were extensive (1.76 million ha) and had significant impacts (6.7\% reduction in the mean annual runoff). The National Invasive Alien Plant Survey found that invasions by a number of high-impact taxa (wattles, pines, and especially eucalypts) were far more extensive than previously thought, and that invasions in the Eastern Cape were far more extensive and denser than previously estimated.

The most comprehensive and accessible source of field data for the whole country is the southern African Plant Invaders Atlas (SAPIA; see Henderson 2001 for a fieldguide, and Henderson and Wilson 2017 for a recent update). SAPIA is based on roadside surveys conducted by Lesley Henderson starting in 1979, and was formalised in 1994 by incorporating observations from participants (adopting many of the citizen science elements of the South African Bird Atlas Project and other such initiatives). As an atlas project, SAPIA is well suited for describing broadscale biogeographical patterns, but it was neither intended nor designed to provide in-depth estimates of the extent of invasions, the efficacy of management interventions, or abundance. It has provided insights into all these aspects and more. SAPIA data are often summarised to show the frequencies of naturalised plant taxa in quarter-degree grid cells (QDGCs), although most data were collected at a finer resolution. SAPIA (accessed May 2018) contains data on 739 terrestrial naturalised plant taxa (note: the list is not the same as that in Appendix 3.1) and shows that naturalised plants have been recorded in $82 \%$ of the 1804 QDGCs in South Africa (Fig. 3.2), with alien plant species richness varying from 1-172 species per QDGC. SAPIA has been very useful for illustrating the national scale of plant invasions (Nel et al. 2004; van Wilgen and Wilson 2018), for elucidating broad-scale drivers of invasions (e.g. Foxcroft et al. 2007; Wilson et al. 2007; Donaldson et al. 2014; Moodley et al. 2014), and for demonstrating the efficacy of control measures (including biological control, Henderson and Wilson 2017).

We used SAPIA and data on native plant species richness at the QDGC scale from the Botanical Database of Southern Africa (BODATSA; accessed December 2018) to compare naturalised and native plant species richness patterns (Fig. 3.2). As in a previous analysis using data in SAPIA collated up to 2004 (Richardson et al. 2005), naturalised plant species richness is highest in the southwest, eastwards along the coast and into the north-eastern corner of the country. However, these patterns are driven by a relatively few widespread species, around a quarter of all naturalised alien plant taxa in SAPIA occur in only one QDGC, and many at only one or a few sites (Fig. 3.3). In many cases, this is not due to climatic restrictions, the lack of detailed surveys, or the limited time to sample potentially invasible habitats, but is rather an artefact of where species were introduced. Morevoer, most widespread invasive plant species are still increasing their ranges (Henderson and Wilson 2017). 

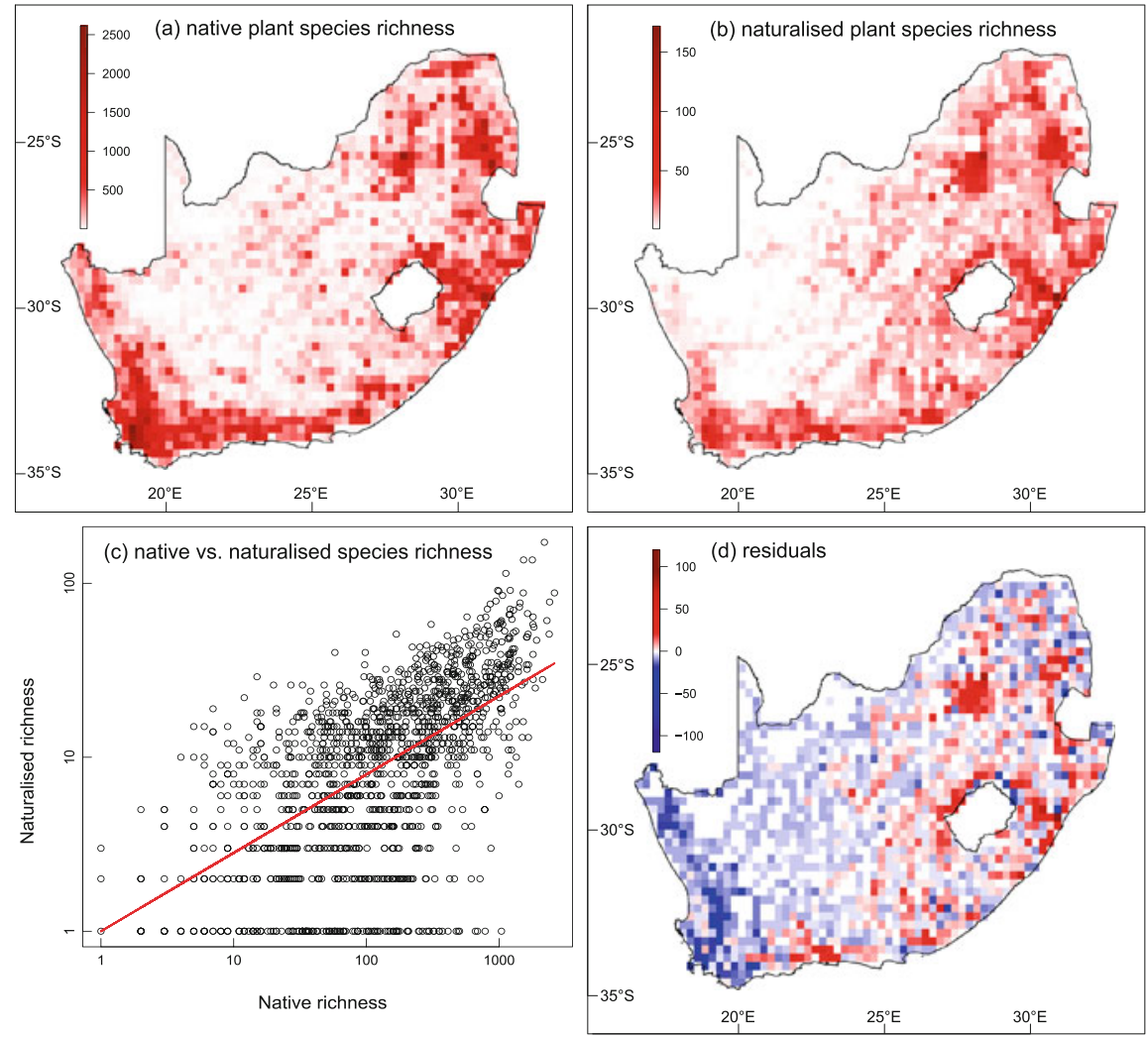

Fig. 3.2 Species richness of (a) native and (b) naturalised plants in quarter-degree grid cells in South Africa. Data for native species are from the Botanical Database of Southern Africa (accessed 3 December 2018) and data for alien species are from the Southern African Plant Invaders Atlas (accessed May 2018). (c) Shows the relationship between native and naturalised plant species richness [ $\log$ (naturalised richness) $=0.45 \mathrm{x} \log$ (native richness); $\mathrm{p}$-value $<2 \mathrm{e}-16$; Pearson $\mathrm{R}=0.60$ ] and (d) shows residuals (cells shaded in blue have fewer alien species than predicted from native species richness; red shading denotes higher alien richness than expected)

This indicates both that South Africa has a substantial invasion debt (Rouget et al. 2016), and that there are many opportunities for pro-active management (i.e. incursion response, Wilson et al. 2013, 2017b; van Wilgen et al. 2020b, Chap. 21). For example, Richardson et al. (2015) produced a graph similar to Fig. 3.3, but only for Australian wattles. Four of the six most widespread invasive wattle species had been introduced for forestry; species introduced for dune stabilisation and as ornamentals had intermediate distributions. Species only found in a few QDGCs had only ever been planted in experimental trials at one or a few sites. Clearing such experimental plantings will likely go a long way to reducing the risk of future invasions (Wilson et al. 2013).

Despite the strong long-lasting signal of introduction effort and the likely dynamic nature of the extent of invasions, patterns of species richness at the scale 


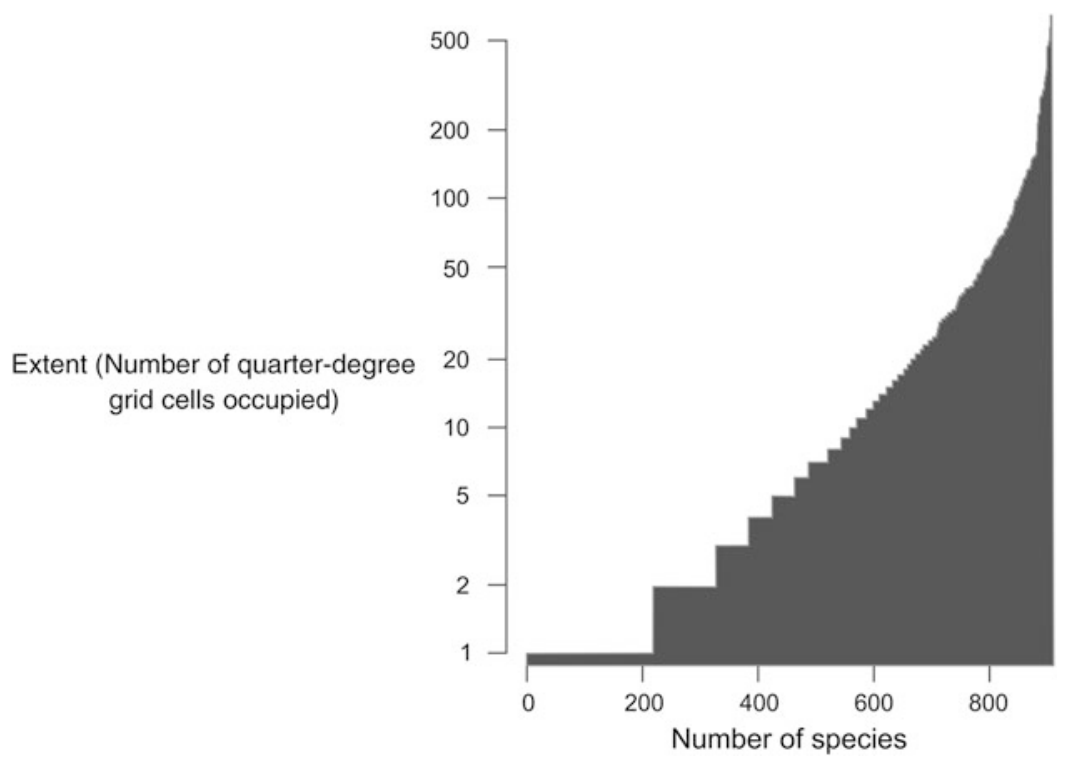

Fig. 3.3 The broad-scale distribution of alien plants in South Africa as per the southern African Plant Invaders Atlas (SAPIA, accessed May 2018). Extent is measured as the occupancy of quarterdegree grid cells out of a total of 1804 cells

of QDGCs are very similar for naturalised and native plants. We suggest that deviation from the observed correlation (Fig. 3.2c, d) are likely due to the uneven introduction effort and propagule pressure over the country and will probably become less pronounced over time.

Another national-scale database on alien plant distribution is the Working for Water Information Management System (WIMS), which was designed to monitor where government funds were spent clearing different species of alien plants. As such, WIMS should be ideal for determining the extent and density of invasions in areas where control has been applied, and for evaluating the effectiveness of control measures. There are unfortunately substantial problems with the accuracy of the taxon-level data captured in WIMS because its focus has been on tracking expenditure (e.g. Marais and Wannenburgh 2008) rather than documenting invasions accurately at the species level. Comparisons of the WIMS data with field observations have highlighted numerous inconsistencies (cf. Kraaij et al. 2017).

Data are also available at local scales and for provincial agencies, but the only other major database on the distribution of alien plants is that initiated and maintained by South African National Parks (see Box 3.2). Such data are fundamental to their mission "to develop, expand, manage and promote a system of sustainable national parks that represents biodiversity and heritage assets, through innovation and best practice for the just and equitable benefit of current and future generations." 


\section{Box 3.2 Plant Invasions in South Africa's National Parks}

South Africa has 19 national parks that cover about 3.9 million ha spread across six terrestrial biomes (first figure below). As is the case with protected areas globally (Foxcroft et al. 2013), South Africa's national parks are increasingly affected by alien plant invasions. A total of 752 alien plant taxa have been recorded in these national parks, of which 386 are known to have naturalised somewhere in South Africa (cf. Foxcroft et al. 2017 and Supplementary Appendix 3.1). The three parks with the highest number of taxa are Kruger NP (363), Table Mountain NP (251) and Garden Route NP (243) (first figure below). Of these, 139 plant taxa are considered 'transformer' species in South African's national parks (Foxcroft et al. 2019). The highest numbers of transformer species are found in Table Mountain NP (74), followed by Garden Route NP (63) and Kruger NP (59). The number of NEM:BA-listed taxa is highest in Kruger (118), followed by Table Mountain (114) and Garden Route (98).

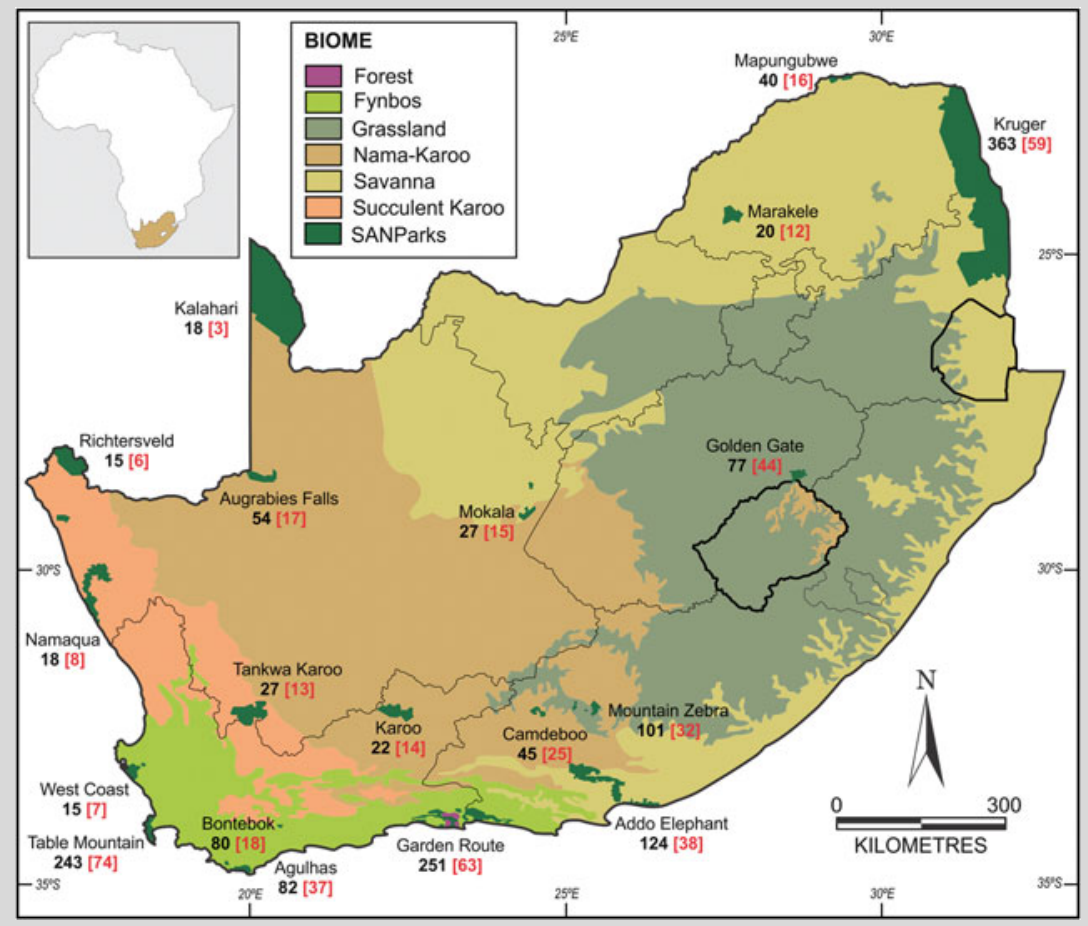

Distribution of South African National Parks, indicating total number of alien plant taxa (Foxcroft et al. 2017) and, in brackets, the number of transformer species (Foxcroft et al. 2019) 


\section{Box 3.2 (continued)}

Many of the alien plants in South African national parks are a legacy of either horticultural plantings or were present on the land before it was incorporated into the park system. The richness (and distinctiveness) of the alien flora of Kruger is partly due to the legacy of gardens in tourist camps (Foxcroft et al. 2008). Garden Route NP and Table Mountain NP also have substantial alien floras that are unique to those parks, and there are low numbers of shared families between these three parks (second figure below). Plant families with the most even representation across parks are Cactaceae (19 parks; 98 park by taxon records) Fabaceae (16; 168), Asteraceae $(16 ; 126)$ and Poaceae $(15 ; 160)$.

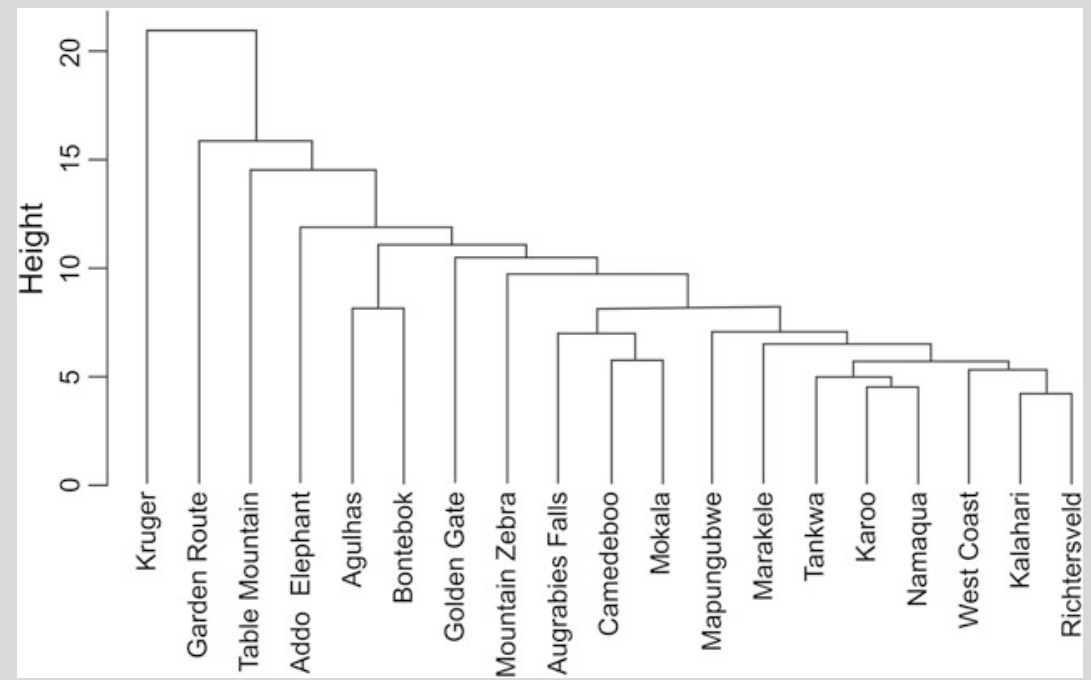

Dendrogram showing levels of similarity of South African national parks on the basis of shared alien plant taxa

The policy of South African National Parks is to phase out all alien plants in staff and tourist facilities, in favour of native (and ideally local) species (Cole et al. 2018). This will take time, and will require not only systematic management programmes to clear existing invasive populations, but also interventions to manage pathways of introduction (Foxcroft et al. 2019), and the establishment of buffer zones around the park (Foxcroft et al. 2011). 


\subsection{The Macroecology of Plant Invasions in South Africa}

\subsubsection{Plant Invasions as a Biogeographical Assay}

Previous research showed that the distribution of naturalised alien plants in South Africa can be viewed as a "biogeographical assay" (Rouget et al. 2015; see also Richardson et al. 2004, 2005). Patterns of distribution, co-occurrence and turnover of well-established alien species at the scale of QDGCs show that "invasive alien [plant] species assemblages" (sensu Rouget et al. 2015) closely match the traditional biomes of South Africa (see van Wilgen et al. 2020a, Chap. 1 Fig. 1.1), which are defined on the basis of native plant biogeography and environmental conditions (Rutherford 1997). We used the latest SAPIA data (see above) to determine an optimum number of "alien plant species assemblage zones" in South Africa, i.e. regions characterised by similar alien plant species composition. Species compositions in QDGCs were compared in a pairwise fashion using the Simpson Dissimilarity Index. Non-metric dimensional scaling (nMDS) was then applied to plot each QGDC in three-dimensions (red-green-blue) so that QDGCs with similar colours have similar species composition (see methodological details in Supplementary Appendix 3.3). A K-means clustering algorithm was then used to identify distinct zones based on consensus over 30 different criteria. Results of the clustering analysis revealed that four zones provide a good summary of current alien plant distribution data at the scale of QDGCs (Fig. 3.4). This contrasts with the six clusters defined by Rouget et al. (2015), based on the number of commonly defined native biomes. Two of the zones defined in Fig. 3.4. ("fynbos-specific invaders" and "grassland-specific invaders") are very similar to clusters defined by Rouget et al. (2015) — these equate closely with the Fynbos and Grassland Biomes of South Africa, respectively. The "moist subtropical invaders" and "semi-arid invaders" zones correspond with the mesic parts of the Savanna Biome, and the interface between the Nama Karoo and arid parts of the Savanna Biome, respectively. Large parts of the Nama Karoo and Succulent Karoo Biomes (a complex mixture of clusters 1, 2 and 3 in Rouget et al. 2015) were not characterised by any cluster in our analysis, as these cells contained fewer records compared to the rest of the country. This low number of records led to biases in the comparisons of QDGCs and prevented the nMDS algorithm from generating sensible results. We believe that the clustering resulting from our analysis provides an ecologically meaningful basis for discussing broad-scale patterns of plant invasions in South Africa. Note that species composition is not perfectly homogeneous within each zone, and that species composition varies gradually in space, even within zones (Supplementary Fig. S3.1). For example, visual inspection of the differences in species composition suggests that the northeastern and southwestern parts of the "grassland-specific invaders" zones are slightly different from each other, as are the northern and southern parts of the "moist subtropical invaders" zone. Finally, we identified "signature taxa" - those that typify each alien plant species assemblage based on the proportion of QDGCs occupied by the taxa that fall within the assemblage. We also identified widespread naturalised taxa that have large parts 


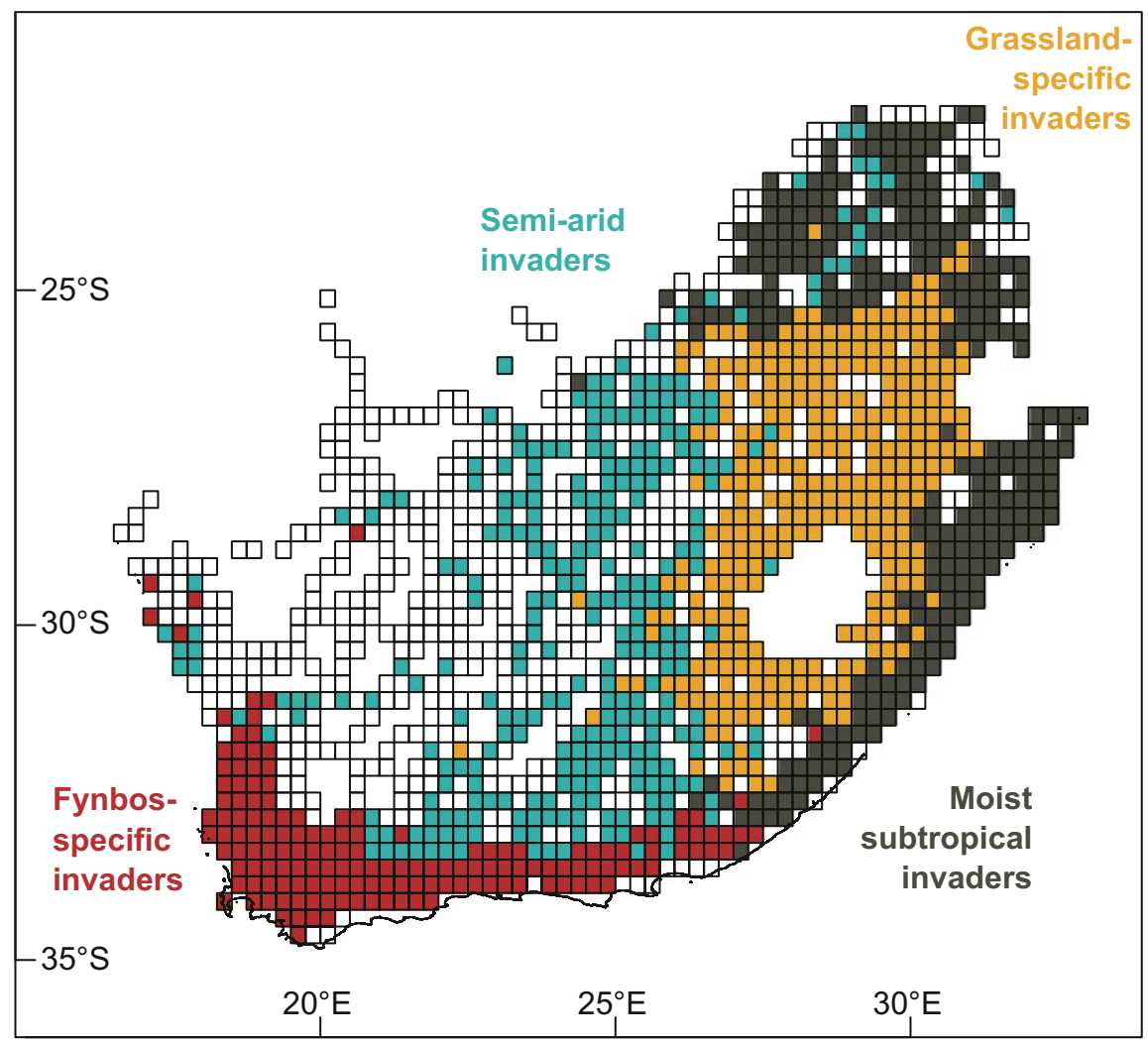

Fig. 3.4 Four "alien plant species assemblage zones" defined by the dissimilarity of naturalised alien plant species composition between quarter-degree grid cells (QDGCs) measured using the Simpson Dissimilarity Index. The centroid of each assemblage was identified in the threedimensional RGB space used to plot each QDGC in Supplementary Fig. S3.1, and was therefore attributed a colour corresponding to its RGB coordinates, representing the compositional difference between the zones (see Supplementary Appendix 3.3). Data are from the southern African Plant Invaders Atlas (SAPIA; accessed May 2018). White cells (those with fewer than five species in the SAPIA database) were excluded from the analyses for computational reasons. Unsampled cells that were not sampled in SAPIA are shown without grid-cell outlines

of their ranges in multiple zones; in many cases such species occur in azonal habitats such a riparian zones; we term this cluster "pervasive/riparian invaders" (Table 3.1).

\subsubsection{Correlates of Alien and Native Species Richness}

We explored the correlates of species richness for alien and native species to assess the relative roles of factors associated with topographic heterogeneity (coefficient of 


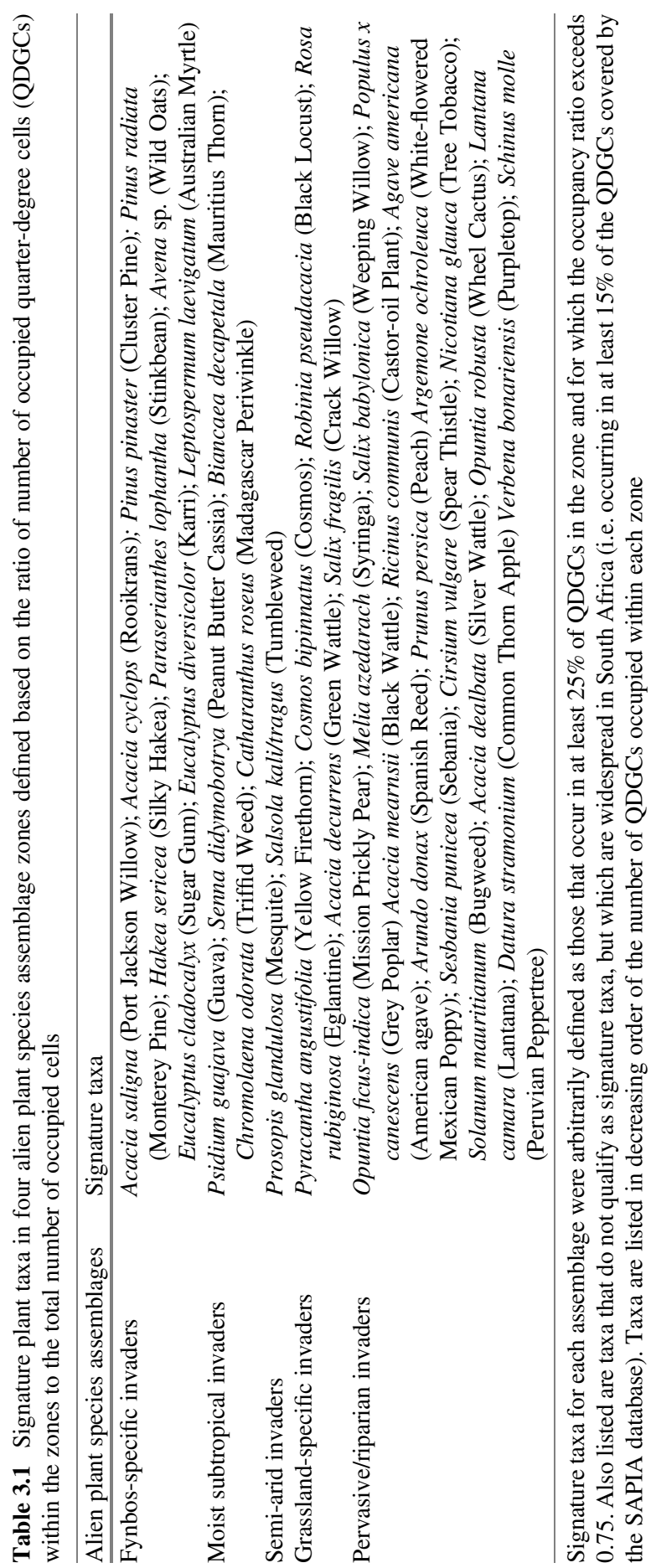


(a) fynbos-specific invaders

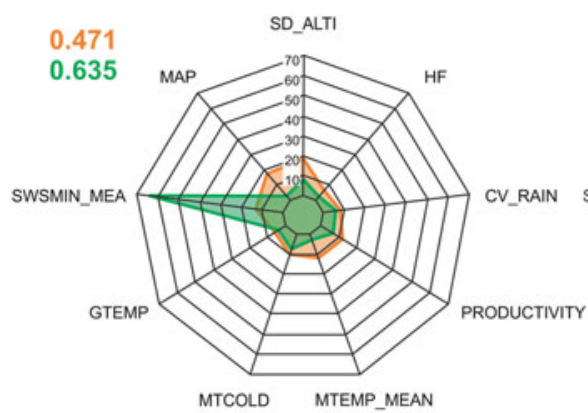

(b) moist subtropical invaders

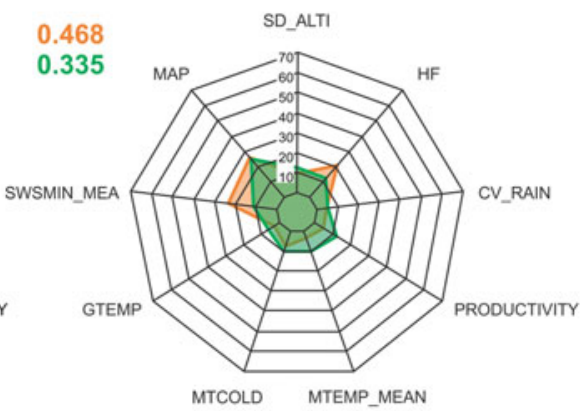

alien species

native species

(c) semi-arid invaders

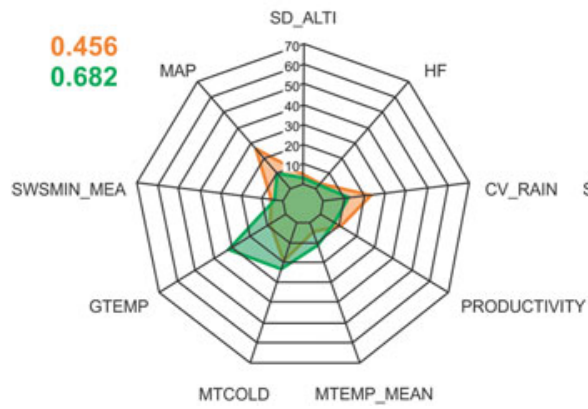

(d) grassland-specific invaders

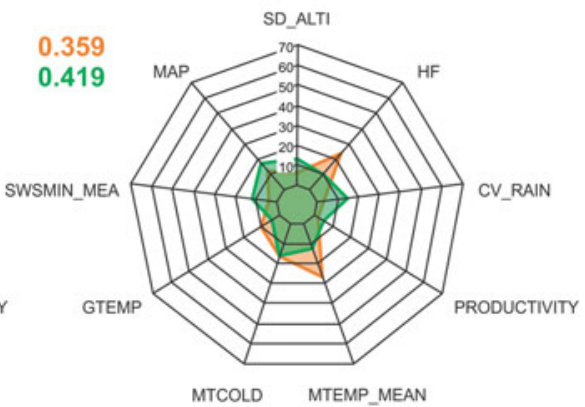

Fig. 3.5 Radar charts showing the relative influence of 9 variables on species richness of naturalised alien (orange) and native (green) plant species for each of the "alien plant species assemblage zones" (Fig. 3.2). (a) fynbos-specific invaders; (b) moist subtropical invaders; (c) semiarid invaders; (d) grassland-specific invaders. The numbers at the top-left of each chart give the variance explained on the cross-validation dataset. SD_ALTI is the standard deviation of altitude; HF is human footprint; CV_RAIN is the coefficient of variation of rainfall; Productivity is mean productivity; MTEMP_MEAN is mean temperature; MTCOLD is mean temperature of the coldest month; GTEMP is Mean Growing Temperature; SWSMIN_MEA is mean soil water stress; and MAP is mean annual precipitation

variation of elevation), environmental favourableness (mean annual precipitation, mean soil water stress, mean growing temperature, mean temperature of the coldest month), energy (mean annual temperature, mean productivity), irregularity (coefficient of variability of rainfall), and human footprint (index of human influence) in structuring diversity patterns (methods are described in Supplementary Appendix 3.4). To do this, we used SAPIA data for alien species and the Botanical Database of Southern Africa data for native plant species at the scale of QDGCs. Previous work showed that species richness of native plants in South Africa could be 
explained by proxies for environmental factors relating to habitat and climatic heterogeneity, favourableness of rainfall and temperature, energy, seasonality of rainfall and temperature metrics, and rainfall irregularity (Cowling et al. 1997). Richardson et al. (2005) and Thuiller et al. (2006) used similar metrics to contrast the relationship between plant species richness for native and alien species (using SAPIA data up to 2004) with indicators of environmental and human-mediated disturbance. We used updated distribution data for naturalised plant taxa (SAPIA data up to 2018) and a similar range of variables to revisit this question with respect to the alien plant species assemblages defined in Fig. 3.4. Results show that determinants of native and naturalised species richness is similar in most zones, although there are some interesting differences (Fig. 3.5). Native plant species richness in the "fynbos-specific invaders" zone is strongly associated with levels of soil water stress. Areas with low moisture stress support higher native species richness than areas with high levels of moisture stress overall. For the "semi-arid invaders" zone, Mean Growing Temperature (GTemp) is important for native species richness, whereas mean Annual Precipitation and the coefficient of variation in rainfall are important determinants of naturalised species richness. For the "grassland-specific invaders" zone, Human Footprint and Mean Temperature are important for naturalised but not native species richness. Interestingly, patterns in naturalised species richness in all zones is largely explained by environmental factors, and human-mediated disturbance is not a major determinant at the QDGC scale. This supports the results of previous research that showed that environmental drivers predict invasion patterns at broad spatial scales, whereas disturbance is important for explaining patterns only at the landscape scale (Rouget and Richardson 2003a, b; see also Wilson et al. 2020, Chap. 13).

\subsection{Conclusions}

South Africa has a long history of plant introductions and invasions, some aspects of which have been well documented and studied. As with all invasions, the current biogeographical patterns offer a snapshot of the outcomes of the ongoing interplay among many factors. These factors include the socio-historical processes that have determined which species have been introduced, and to which sites, the traits of the alien species, and features of the recipient ecosystems, and in many cases the multifaceted role of humans in influencing invasions. The study of the biogeography of South African terrestrial plant invasions has been highly productive, but many questions remain. For example, research is needed to better understand the introduction dynamics and how processes of introduction, cultivation and dissemination interact with environmental features to shape major plant "invasion syndromes" (sensu Kueffer et al. 2013) in South Africa. Understanding the biogeography of plant invasions is a crucial prerequisite for effective planning. In this regard, we suggest several priorities for future research. 
There is an urgent need for an accurate alien flora for South Africa, both to ensure that current invasions are properly managed, and that the risk of future invasions can be identified and minimised (see Sect. 3.3.1, and Kumschick et al. 2020, Chap. 20, for more details). The alien flora should include objective information on the introduction status of each taxon according to the unified framework for biological invasions (Blackburn et al. 2011; Wilson et al. 2018). It should be updated regularly as part of the processes for completion of the triennial national status reports mandated in legislation (van Wilgen and Wilson 2018).

"Alien plant species assemblage zones" (Fig. 3.4) reflect the outcome of decades of alien plant taxa arranging themselves in space following human-mediated introduction and dissemination and interactions with environmental (Wilson et al. 2020, Chap 13) and biotic (Le Roux et al. 2020, Chap 14) features of South African ecosystems. The dimensions and determinants of these species assemblages and the zones they occupy deserve further attention; these zones potentially define ecologically meaningful spatial units for national-scale planning (Fig. 3.4).

There is also a need for a systematic monitoring system to detect and track invasions (Latombe et al. 2017). This should incorporate active on-ground surveillance, remote sensing, and citizen science initiatives [e.g. expanding SAPIA to tap into iNaturalist (https://www.inaturalist.org/), and drone and satellite technology]. Visser et al. (2014) showed the value of freely available Google Earth imagery for detecting changes in the distribution of invasive alien plants, especially trees. A series of sentinel sites could be established to allow for the monitoring of the extent of invasions of key taxa and sites.

The dimensions of the invasion debt in South Africa's alien flora requires much more research. Many naturalised species are clearly poised to invade large areas; the potential ranges of these species need to be determined to inform response efforts.

Acknowledgements Much of the work reviewed in this chapter was supported by the DSI-NRF Centre of Excellence for Invasion Biology. We salute Lesley Henderson for her dedication to the collation of distribution data that now forms the Southern African Plant Invader Atlas (SAPIA) and thank her for responses to many questions during the preparation of the chapter. Many other colleagues also provided insights on many topics. The South African Department of Environment, Forestry, and Fisheries (DEFF) are thanked for funding the South African National Biodiversity Institute noting that this publication does not necessarily represent the views or opinions of DEFF or its employees.

\section{Electronic Supplementary Material}

The online version of this chapter contains supplementary material, which is available to authorised users: Supplementary Appendix 3.1 (https://doi.org/10.5281/ zenodo.3562046); Supplementary Appendices 3.2-3.4 (https://doi.org/10.5281/ zenodo.3660871). 


\section{References}

Alston KP, Richardson DM (2006) The roles of habitat features, disturbance, and distance from putative source populations in structuring alien plant invasions at the urban/wildland interface on the Cape Peninsula, South Africa. Biol Conserv 132:183-198. https://doi.org/10.1016/j. biocon.2006.03.023

Annecke DP, Moran VC (1978) Critical reviews of biological pest control in South Africa. 2. The prickly pear, Opuntia ficus-indica (L.) Miller. J Entomol Soc South Afr 41:161-188

Avis AM (1989) A review of coastal dune stabilization in the Cape Province of South Africa. Landscape Urban Plan 18:55-68. https://doi.org/10.1016/0169-2046(89)90055-8

Bhagat SA, Breman E, Thekaekara T et al (2012) A battle lost? Report on two centuries of invasion and management of Lantana camara L. in Australia, India and South Africa. PLoS One 7: e32407. https://doi.org/10.1371/journal.pone.0032407

Blackburn TM, Pyšek P, Bacher S et al (2011) A proposed unified framework for biological invasions. Trends Ecol Evol 26:333-339. https://doi.org/10.1016/j.tree.2011.03.023

Canavan S, Richardson DM, Le Roux JJ et al (2019) Alien bamboos in South Africa: a sociohistorical perspective. Hum Ecol 47:121-133. https://doi.org/10.1007/s10745-018-0041-8

Cole N, van Wilgen NJ, Foxcroft LC et al (2018) Invasive alien species management. South African National Parks policy document. Reference number: 17/P-CSD/Pol/AIS (09-17) v1

Cowling RM, Richardson DM, Schulze RE et al (1997) Species diversity at the regional scale. In: Cowling RM, Richardson DM, Pierce SM (eds) Vegetation of Southern Africa. Cambridge University Press, Cambridge, pp 447-473

Cronin K, Kaplan H, Gaertner M et al (2017) Aliens in the nursery: assessing the attitudes of nursery managers to invasive species regulations. Biol Invasions 19:925-937. https://doi.org/ 10.1007/s10530-016-1363-3

Deacon J (1986) Human settlement in South Africa and archaeological evidence for alien plants and animals. In: Macdonald IAW, Kruger FJ, Ferrar AA (eds) The ecology and management of biological invasions in southern Africa. Oxford University Press, Cape Town, pp 3-19

Donaldson JE, Hui C, Richardson DM et al (2014) Invasion trajectory of alien trees: the role of introduction pathway and planting history. Glob Chang Biol 20:1527-1537. https://doi.org/10. $1111 / \mathrm{gcb} .12486$

Driscoll D, Catford JA, Barney JN et al (2014) New pasture plants intensify invasive species risk. Proc Natl Acad Sci U S A 111:16622-16627. https://doi.org/10.1073/pnas.1409347111

Faulkner KT, Burness A, Byrne MJ et al (2020) South Africa's pathways of introduction and dispersal and how they have changed over time. In: van Wilgen BW, Measey J, Richardson DM, Wilson JR, Zengeya TA (eds) Biological invasions in South Africa. Springer, Berlin, pp 311352. https://doi.org/10.1007/978-3-030-32394-3_12

Foxcroft LC, Rouget M, Richardson DM et al (2004) Reconstructing fifty years of Opuntia stricta invasion in the Kruger National Park: environmental determinants and propagule pressure. Divers Distrib 10:427-437. https://doi.org/10.1111/j.1366-9516.2004.00117.x

Foxcroft LC, Richardson DM, Wilson JRU (2008) Ornamental plants as invasive aliens: problems and solutions in the Kruger National Park, South Africa. Environ Manage 41:32-51. https://doi. org/10.1007/s00267-007-9027-9

Foxcroft LC, Jarošík V, Pyšek P et al (2011) Protected area boundaries as a natural filter of plant invasions from surrounding landscapes. Conserv Biol 25:400-405. https://doi.org/10.1111/j. 1523-1739.2010.01617.x

Foxcroft LC, Pyšek P, Richardson DM et al (eds) (2013) Plant invasions in protected areas: patterns, problems and challenges, Invading nature series, vol vol 7. Springer, Berlin. https://doi.org/10. 1007/978-94-007-7750-7

Foxcroft LC, van Wilgen NJ, Baard J et al (2017) Biological invasions in South African National Parks. Bothalia 47(2):a2158. https://doi.org/10.4102/abc.v47i2.2158 
Foxcroft LC, Spear D, van Wilgen NJ et al (2019) Assessing the association between pathways of alien plant invaders and their impacts in protected areas. NeoBiota 43:1-25. https://doi.org/10. 3897/neobiota.43.29644

Foxcroft LC, van Wilgen BW, Abrahams B et al (2020) Knowing-doing continuum or knowingdoing gap? Information flow between researchers and managers of biological invasions in South Africa. In: van Wilgen BW, Measey J, Richardson DM, Wilson JR, Zengeya TA (eds) Biological invasions in South Africa. Springer, Berlin, pp 827-850. https://doi.org/10.1007/ 978-3-030-32394-3_28

Galatowitsch SM, Richardson DM (2005) Riparian scrub recovery after clearing of invasive alien trees in headwater streams of the Western Cape, South Africa. Biol Conserv 122:509-521. https://doi.org/10.1016/j.biocon.2004.09.008

Glen HF (2002) Cultivated plants of Southern Africa: botanical names, common names, origins, literature. National Botanical Institute, Jacana

Glen H, van Wyk B (2016) Guide to the trees introduced into South Africa. Struik Nature, Cape Town

Goodall JM, Erasmus DJ (1996) Review of the status and integrated control of the invasive alien weed, Chromolaena odorata, in South Africa. Agr Ecosys Environ 56:151-164. https://doi.org/ 10.1016/0167-8809(95)00647-8

Goodall J, Witkowski ETF, Morris CD et al (2011) Are environmental factors important facilitators of pompom weed (Campuloclinium macrocephalum) invasion in South African rangelands? Biol Invasions 13:2217-2231. https://doi.org/10.1007/s10530-011-0035-6

Greve M, Eric C, von der Meden O et al (2020) Biological invasions in South Africa's offshore sub-Antarctic territories. In: van Wilgen BW, Measey J, Richardson DM, Wilson JR, Zengeya TA (eds) Biological invasions in South Africa. Springer, Berlin, pp 205-226. https://doi.org/10. 1007/978-3-030-32394-3_8

Harding GB, Bate GC (1991) The occurrence of invasive Prosopis species in the north-western Cape, South Africa. S Afr J Sci 87:188-192

Henderson L (1983) Barrier plants in South Africa. Bothalia 14:635-639. https://doi.org/10.4102/ abc.v14i3/4.1221

Henderson L (2001) Alien weeds and invasive plants - a complete guide to declared weeds and invaders in South Africa. Plant Protection Research Institute Handbook 12. Agricultural Research Council, Pretoria

Henderson L, Wells MJ (1986) Alien plant invasions in the grassland and savanna biomes. In: Macdonald IAW, Kruger FJ, Ferrar AA (eds) The ecology and management of biological invasions in Southern Africa. Oxford University Press, Cape Town, pp 109-118

Henderson L, Wilson JRU (2017) Changes in the composition and distribution of alien plants in South Africa: an update from the Southern African plant invaders atlas. Bothalia 47(2):a2172. https://doi.org/10.4102/abc.v47i2.2172

Hill MP, Coetzee JA, Martin GD et al (2020a) Invasive alien aquatic plants in South African freshwater ecosystems. In: van Wilgen BW, Measey J, Richardson DM, Wilson JR, Zengeya TA (eds) Biological invasions in South Africa. Springer, Berlin, pp 95-112. https://doi.org/10. 1007/978-3-030-32394-3_4

Hill MP, Moran VC, Hoffmann JH et al (2020b) More than a century of biological control against invasive alien plants in South Africa: a synoptic view of what has been accomplished. In: van Wilgen BW, Measey J, Richardson DM, Wilson JR, Zengeya TA (eds) Biological invasions in South Africa. Springer, Berlin, pp 549-568. https://doi.org/10.1007/978-3-030-32394-3_19

Holmes PM, Richardson DM, Esler KJ et al (2005) A decision-making framework for restoring riparian zones degraded by invasive alien plants in South Africa. S Afr J Sci 101:553-564

Holmes PM, Esler KJ, Gaertner M et al (2020) Biological invasions and ecological restoration in South Africa. In: van Wilgen BW, Measey J, Richardson DM, Wilson JR, Zengeya TA (eds) Biological invasions in South Africa. Springer, Berlin, pp 661-696. https://doi.org/10.1007/ 978-3-030-32394-3_23 
Irlich UM, Richardson DM, Davies SJ et al (2014) Climate change and alien species in South Africa. In: Ziska LH, Dukes JS (eds) Invasive species and global climate change. CAB International, Wallingford, UK, pp 129-147. https://doi.org/10.1079/9781780641645.0129

Jacobs L, Richardson DM, Wilson JRU (2014) Melaleuca parvistaminea Byrnes (Myrtaceae) in South Africa: invasion risk and feasibility of eradication. S Afr J Bot 94:24-32. https://doi.org/ 10.1016/j.sajb.2014.05.002

Jacobs LEO, Richardson DM, Lepschi B et al (2017) Quantifying errors and omissions in alien species lists: the introduction status of Melaleuca species in South Africa as a case study. NeoBiota 32:89-105. https://doi.org/10.3897/neobiota.32.9842

Kaplan H, Wilson JRU, Klein $\mathrm{H}$ et al (2017) A proposed national strategic framework for the management of Cactaceae in South Africa. Bothalia 47(2):a2149. https://doi.org/10.4102/abc. v47i2.2149

Kotzé I, Beukes H, van den Berg E et al (2010) National invasive Alien Plant Survey. Report No. GW/A/2010/21, Agricultural Research Council - Institute for Soil, Climate and Water, Pretoria

Kotzé JDF, Beukes HB, Seifert T (2019) Essential environmental variables to include in a stratified sampling design for a national-level invasive alien tree survey. iForest 12:418-426. https://doi. org/10.3832/ifor2767-012

Kraaij T, Baard JA, Rikhotso DR et al (2017) Assessing the effectiveness of invasive alien plant management in a large fynbos protected area. Bothalia 47:a2105. https://doi.org/10.4102/abc. v47i2.2105

Kueffer C, Pyšek P, Richardson DM (2013) Integrative invasion science: model systems, multi-site studies, focused meta-analysis, and invasion syndromes. New Phytol 200:615-633. https://doi. org/10.1111/nph.12415

Kumschick S, Foxcroft LC, Wilson JR (2020) Analysing the risks posed by biological invasions to South Africa. In: van Wilgen BW, Measey J, Richardson DM, Wilson JR, Zengeya TA (eds) Biological invasions in South Africa. Springer, Berlin, pp 569-592. https://doi.org/10.1007/ 978-3-030-32394-3_20

Latombe G, Pyšek P, Jeschke JM et al (2017) A vision for global monitoring of biological invasions. Biol Conserv 213:295-308. https://doi.org/10.1016/j.biocon.2016.06.013

Le Maitre DC, de Lange WJ, Richardson DM et al (2011) The economic consequences of environmental impacts of alien plant invasions in South Africa. In: Pimentel D (ed) Biological invasions. Environmental and economic costs of alien plant, animal and microbe invasions, 2nd edn. CRC, Boca Raton, FL, pp 295-323. https://doi.org/10.1201/b10938-22

Le Maitre DC, Blignaut JN, Clulow A et al (2020) Impacts of plant invasions on terrestrial water flows in South Africa. In: van Wilgen BW, Measey J, Richardson DM, Wilson JR, Zengeya TA (eds) Biological invasions in South Africa. Springer, Berlin, pp 429-456. https://doi.org/10. 1007/978-3-030-32394-3_15

Le Roux JJ, Geerts S, Ivey P et al (2010) Molecular systematics and ecology of invasive Kangaroo Paws in South Africa: management implications for a horticulturally important genus. Biol Invasions 12:3989-4002. https://doi.org/10.1007/s10530-010-9818-4

Le Roux JJ, Clusella-Trullas S, Mokotjomela TM et al (2020) Biotic interactions as mediators of biological invasions: insights from South Africa. In: van Wilgen BW, Measey J, Richardson DM, Wilson JR, Zengeya TA (eds) Biological invasions in South Africa. Springer, Berlin, pp 385-428. https://doi.org/10.1007/978-3-030-32394-3_14

Lukey P, Hall J (2020) Biological invasion policy and legislation development and implementation in South Africa. In: van Wilgen BW, Measey J, Richardson DM, Wilson JR, Zengeya TA (eds) Biological invasions in South Africa. Springer, Berlin, pp 513-548. https://doi.org/10.1007/ 978-3-030-32394-3_18

Macdonald IAW, Frame GW (1988) The invasion of introduced species into nature reserves in tropical savannas and dry woodlands. Biol Conserv 44:67-93. https://doi.org/10.1016/00063207(88)90005-5 
Magona N, Richardson DM, Le Roux JJ et al (2018) Even well studied groups of alien species are poorly inventoried: Australian Acacia species in South Africa as a case study. NeoBiota 39:1-29

Marais C, Wannenburgh A (2008) Restoration of water resources (natural capital) through the clearing of invasive alien plants from riparian areas in South Africa-costs and water benefits. S Afr J Bot 74:526-537

Marais C, van Wilgen BW, Stevens D (2004) The clearing of invasive alien plants in South Africa: a preliminary assessment of costs and progress. S Afr J Sci 100:97-103

Mazibuko DM (2012) Phylogenetic relationship of Prosopis in South Africa: an assessment of the extent of hybridization, and the role of genome size and seed size in the invasion dynamics. MSc Thesis, Stellenbosch University, Stellenbosch

McConnachie AJ, Strathie LW, Mersie W et al (2011) Current and potential geographical distribution of the invasive plant Parthenium hysterophorus (Asteraceae) in eastern and southern Africa. Weed Res 51:71-84. https://doi.org/10.1111/j.1365-3180.2010.00820.x

McConnachie MM, Richardson DM, van Wilgen BW et al (2015) Estimating the effect of plantations on pine invasions in protected areas: a case study from South Africa. J Appl Ecol 52:110-118. https://doi.org/10.1111/1365-2664.12366

McLean P, Gallien L, Wilson JRU et al (2017) Small urban centres as launching sites for plant invasions in natural areas: insights from South Africa. Biol Invasions 19:3541-3555. https://doi. org/10.1007/s10530-017-1600-4

Milton SJ (2004) Grasses as invasive alien plants in South Africa. S Afr J Sci 100:69-75

Moodley D, Geerts S, Rebelo T et al (2014) Site-specific conditions influence plant naturalization: the case of alien Proteaceae in South Africa. Acta Oecol 59:62-71. https://doi.org/10.1016/j. actao.2014.05.005

Nel JL, Richardson DM, Rouget M et al (2004) A proposed classification of invasive alien plant species in South Africa: towards prioritising species and areas for management action. S Afr J Sci 100(53-64):788

Novoa A, Le Roux JJ, Robertson MP et al (2015) Introduced and invasive cactus species: a global review. AoB Plants 7:plu078. https://doi.org/10.1093/aobpla/plu078

Novoa A, Le Roux JJ, Richardson DM et al (2017) Level of environmental threat posed by horticultural trade in Cactaceae. Conserv Biol 31:1066-1075. https://doi.org/10.1111/cobi. 12892

O'Connor T, van Wilgen BW (2020) The impact of invasive alien plants on rangelands in South Africa. In: van Wilgen BW, Measey J, Richardson DM, Wilson JR, Zengeya TA (eds) Biological invasions in South Africa. Springer, Berlin, pp 457-486. https://doi.org/10.1007/ 978-3-030-32394-3_16

Potgieter LJ, Douwes E, Gaertner M et al (2020) Biological invasions in South Africa's urban ecosystems: patterns, processes, impacts and management. In: van Wilgen BW, Measey J, Richardson DM, Wilson JR, Zengeya TA (eds) Biological invasions in South Africa. Springer, Berlin, pp 273-310. https://doi.org/10.1007/978-3-030-32394-3_11

Poynton RJ (1979a) Tree planting in Southern Africa, The pines, vol 1. Department of Forestry, Pretoria

Poynton RJ (1979b) Tree planting in Southern Africa, The eucalypts, vol 2. Department of Forestry, Pretoria

Poynton RJ (1984) Characteristics and uses of selected trees and shrubs cultivated in South Africa. Bull 39, 4th ed, revised edn. Government Printer, Pretoria

Poynton RJ (1990) The genus Prosopis in southern Africa. S Afr For J 152:62-66. https://doi.org/ $10.1080 / 00382167.1990 .9629020$

Poynton RJ (2009) Tree planting in southern Africa: other genera. Department of Forestry, Pretoria

Pyšek P, Richardson DM, Rejmánek M et al (2004) Alien plants in checklists and floras: towards better communication between taxonomists and ecologists. Taxon 53:131-143. https://doi.org/ $10.2307 / 4135498$

Pyšek P, Hulme PE, Meyerson LA et al (2013) Hitting the right target: taxonomic challenges of, and for, biological invasions. AoB Plants 5:plt042. https://doi.org/10.1093/aobpla/plt042 
Richardson DM (1998) Forestry trees as invasive aliens. Conserv Biol 12:18-26. https://doi.org/10. 1046/j.1523-1739.1998.96392.x

Richardson DM, Brown PJ (1986) Invasion of Mesic mountain fynbos by Pinus radiata. S Afr J Bot 52:529-536. https://doi.org/10.1016/S0254-6299(16)31486-7

Richardson DM, Cowling RM (1992) Why is mountain fynbos invasible and which species invade? In: van Wilgen BW, Richardson DM, Kruger FJ et al (eds) Fire in South African mountain fynbos. Springer, Berlin, pp 161-181. https://doi.org/10.1007/978-3-642-76174-4_9

Richardson DM, Higgins SI (1998) Pines as invaders in the southern hemisphere. In: Richardson DM (ed) Ecology and biogeography of Pinus. Cambridge University Press, Cambridge, pp 450-473

Richardson DM, Kluge RL (2008) Seed banks of invasive Australian Acacia species in South Africa: role in invasiveness and options for management. Perspect Plant Ecol Evol Syst 10:161-177. https://doi.org/10.1016/j.ppees.2008.03.001

Richardson DM, Pyšek P (2012) Naturalization of introduced plants: ecological drivers of biogeographic patterns. New Phytol 196:383-396. https://doi.org/10.1111/j.1469-8137.2012. 04292.x

Richardson DM, Rejmánek M (2011) Trees and shrubs as invasive alien species - a global review. Divers Distrib 17:788-809. https://doi.org/10.1111/j.1472-4642.2011.00782.x

Richardson DM, Thuiller W (2007) Home away from home - objective mapping of high-risk source areas for plant introductions. Divers Distrib 13:299-323. https://doi.org/10.1111/j.14724642.2007.00337.x

Richardson DM, van Wilgen BW (2004) Invasive alien plants in South Africa: how well do we understand the ecological impacts? S Afr J Sci 100:45-52

Richardson DM, Pyšek P, Carlton JT (2011a) A compendium of essential concepts and terminology in invasion ecology. In: Richardson DM (ed) Fifty years of invasion ecology. The legacy of Charles Elton. Wiley-Blackwell, Oxford, pp 409-420. https://doi.org/10.1002/9781444329988. $\operatorname{ch} 30$

Richardson DM, Wilson JRU, Weyl OLF et al (2011b) South Africa: invasions. In: Simberloff D, Rejmánek M (eds) Encyclopedia of biological invasions. University of California Press, Berkeley, pp 643-651

Richardson DM, Williams PA, Hobbs RJ (1994) Pine invasions in the Southern Hemisphere: determinants of spread and invadability. J Biogeogr 21:511-527. https://doi.org/10.2307/ 2845655

Richardson DM, Macdonald IAW, Hoffmann JH et al (1997) Alien plant invasions. In: Cowling RM, Richardson DM, Pierce SM (eds) Vegetation of Southern Africa. Cambridge University Press, Cambridge, pp 535-570

Richardson DM, Bond WJ, Dean WRJ et al (2000) Invasive alien organisms and global change: a South African perspective. In: Mooney HA, Hobbs RJ (eds) Invasive species in a changing world. Island Press, Washington DC, pp 303-349

Richardson DM, Cambray JA, Chapman RA et al (2003) Vectors and pathways of biological invasions in South Africa - past, present and future. In: Ruiz G, Carlton J (eds) Invasive species: vectors and management strategies. Island Press, Washington DC, pp 292-349

Richardson DM, Rouget RM, Henderson L, Nel JL (2004) Invasive alien plants in South Africa: macroecological patterns, with special emphasis on the Cape Floristic Region. In: Arianoutsou M, Papanastasis V (eds) Proceedings of 10th MEDECOS conference, April 25May 1, Rhodes, Greece. Millpress, Rotterdam

Richardson DM, Rouget M, Ralston SJ et al (2005) Species richness of alien plants in South Africa: environmental correlates and the relationship with indigenous plant species richness. Ecoscience 12:391-402. https://doi.org/10.2980/i1195-6860-12-3-391.1

Richardson DM, Hui C, Nunez M et al (2014) Tree invasions: patterns, processes, challenges and opportunities. Biol Invasions 16:473-481. https://doi.org/10.1007/s10530-013-0606-9

Richardson DM, Le Roux JJ, Wilson JRU (2015) Australian acacias as invasive species: lessons to be learnt from regions with long planting histories. South For 77:31-39. https://doi.org/10.2989/ 20702620.2014.999305 
Rouget M, Richardson DM (2003a) Inferring process from pattern in alien plant invasions: a semimechanistic model incorporating propagule pressure and environmental factors. Am Nat 162:713-724. https://doi.org/10.1086/379204

Rouget M, Richardson DM (2003b) Understanding patterns of plant invasion at different spatial scales: quantifying the roles of environment and propagule pressure. In: Child LE, Brock JH, Brundu G et al (eds) Plant invasions: ecological threats and management solutions. Backhuys, Leiden, pp 3-15

Rouget M, Richardson DM, Nel JA et al (2002) Commercially-important trees as invasive aliens towards spatially explicit risk assessment at a national scale. Biol Invasions 4:397-412

Rouget M, Richardson DM, Nel JL et al (2004) Mapping the potential spread of major plant invaders in South Africa using climatic suitability. Divers Distrib 10:475-484. https://doi.org/ 10.1111/j.1366-9516.2004.00118.x

Rouget M, Hui C, Renteria J et al (2015) Plant invasions as a biogeographical assay: vegetation biomes constrain the distribution of invasive alien species assemblages. S Afr J Bot 101:24-31. https://doi.org/10.1016/j.sajb.2015.04.009

Rouget M, Robertson MP, Wilson JRU et al (2016) Invasion debt-quantifying future biological invasions. Divers Distrib 22:445-456. https://doi.org/10.1111/ddi.12408

Rundel PW, Dickie IE, Richardson DM (2014) Tree invasions into treeless areas: mechanisms and ecosystem processes. Biol Invasions 16:663-675. https://doi.org/10.1007/s10530-0130614-9

Rutherford MC (1997) Categorization of biomes. In: Cowling RM, Richardson DM, Pierce SM (eds) Vegetation of Southern Africa. Cambridge University Press, Cambridge, pp 91-98

Shackleton RT, Novoa A, Shackleton CM et al (2020) The social dimensions of biological invasions in South Africa. In: van Wilgen BW, Measey J, Richardson DM, Wilson JR, Zengeya TA (eds) Biological invasions in South Africa. Springer, Berlin, pp 697-726. https://doi.org/10. 1007/978-3-030-32394-3_24

Terblanche C, Nänni I, Kaplan H et al (2016) An approach to the development of a national strategy for controlling invasive alien plant species: the case of Parthenium hysterophorus in South Africa. Bothalia 46:a2053. https://doi.org/10.4102/abc.v46i1.2053

Thuiller W, Richardson DM, Rouget M et al (2006) Interactions between environment, species traits, and human uses describe patterns of plant invasions. Ecology 87:1755-1769. https://doi. org/10.1890/0012-9658(2006)87[1755:IBESTA]2.0.CO;2

van den Berg EC, Kotze I, Beukes H (2013) Detection, quantification and monitoring of Prosopis in the Northern Cape Province of South Africa using remote sensing and GIS. S Afr J Geomatics 2:68-81

van Wilgen BW, Richardson DM (2012) Three centuries of managing introduced conifers in South Africa: benefits, impacts, changing perceptions and conflict resolution. J Environ Manag 106:56-68. https://doi.org/10.1016/j.jenvman.2012.03.052

van Wilgen BW, Wilson JR (eds) (2018) The status of biological invasions and their management in South Africa in 2017. S Afr Nat Biodiv Inst, Cape Town and DST-NRF Cent Excel Invas Biol, Stellenbosch

Van Wilgen BW, Carruthers J, Cowling RM et al (2016) Ecological research and conservation management in the Cape Floristic Region between 1945 and 2015: history, current understanding and future challenges. Trans R Soc S Afr 71:207-303. https://doi.org/10.1080/0035919X. 2016.1225607

van Wilgen BW, Measey J, Richardson DM, Wilson JR, Zengeya TA (2020a) Biological invasions in South Africa: an overview. In: van Wilgen BW, Measey J, Richardson DM, Wilson JR, Zengeya TA (eds) Biological invasions in South Africa. Springer, Berlin, pp 3-30. https://doi. org/10.1007/978-3-030-32394-3_1

van Wilgen BW, Wilson JR, Wannenburgh A et al (2020b) The extent and effectiveness of alien plant control projects in South Africa. In: van Wilgen BW, Measey J, Richardson DM, Wilson JR, Zengeya TA (eds) Biological invasions in South Africa. Springer, Berlin, pp 593-624. https://doi.org/10.1007/978-3-030-32394-3_21 
Versfeld DB, Le Maitre DC, Chapman RA (1998) Alien invading plants and water resources in South Africa: a preliminary assessment. Report no. TT99/98. Water Research Commission, Pretoria

Visser V, Langdon B, Pauchard A et al (2014) Unlocking the potential of Google Earth as a tool in invasion science. Biol Invasions 16:513-534. https://doi.org/10.1007/s10530-013-0604-y

Visser V, Wilson JRU, Brown C et al (2017) Grasses as invasive plants in South Africa revisited: patterns, pathways and management. Bothalia 47(2):a2169. https://doi.org/10.4102/abc.v47i2. 2169

Walters M, Figueiredo E, Crouch NR et al (2011) Naturalised and invasive succulents of southern Africa. Abc Taxa, Belguim

Wells MJ, Poynton RJ, Balsinhas AA et al (1986) The history of introduction of invasive alien plants to southern Africa. In: IAW M, Kruger FJ, Ferrar AA (eds) The ecology and management of biological invasions in southern Africa. Oxford University Press, South Africa, pp 21-35

Wilson JRU, Richardson DM, Rouget M et al (2007) Residence time and potential range: crucial considerations in modelling plant invasions. Divers Distrib 13:11-22. https://doi.org/10.1111/j. 1366-9516.2006.00302.x

Wilson JRU, Ivey P, Manyama P et al (2013) A new national unit for invasive species detection, assessment and eradication planning. S Afr J Sci 109:0113. https://doi.org/10.1590/sajs.2013/ 20120111

Wilson JRU, Gaertner M, Richardson DM et al (2017a) Contributions to the National Status Report on biological invasions in South Africa. Bothalia 47(2):a2207. https://doi.org/10.4102/abc. v47i2.2207

Wilson JR, Panetta FD, Lindgren C (2017b) Detecting and responding to alien plant incursions. Cambridge University Press, Cambridge, UK

Wilson JRU, Faulkner KT, Rahlao SJ et al (2018) Indicators for monitoring biological invasions at a national level. J Appl Ecol 55:2612-2620. https://doi.org/10.1111/1365-2664.13251

Wilson JR, Foxcroft LC, Geerts S et al (2020) The role of environmental factors in promoting and limiting biological invasions in South Africa. In: van Wilgen BW, Measey J, Richardson DM, Wilson JR, Zengeya TA (eds) Biological invasions in South Africa. Springer, Berlin, pp 353-384. https://doi.org/10.1007/978-3-030-32394-3_13

Zengeya TA, Kumschick S, Weyl OLF et al (2020) An evaluation of the impacts of alien species on biodiversity in South Africa using different assessment methods. In: van Wilgen BW, Measey J, Richardson DM, Wilson JR, Zengeya TA (eds) Biological invasions in South Africa. Springer, Berlin, pp 487-512. https://doi.org/10.1007/978-3-030-32394-3_17

Open Access This chapter is licensed under the terms of the Creative Commons Attribution 4.0 International License (http://creativecommons.org/licenses/by/4.0/), which permits use, sharing, adaptation, distribution and reproduction in any medium or format, as long as you give appropriate credit to the original author(s) and the source, provide a link to the Creative Commons licence and indicate if changes were made.

The images or other third party material in this chapter are included in the chapter's Creative Commons licence, unless indicated otherwise in a credit line to the material. If material is not included in the chapter's Creative Commons licence and your intended use is not permitted by statutory regulation or exceeds the permitted use, you will need to obtain permission directly from the copyright holder.

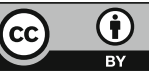

